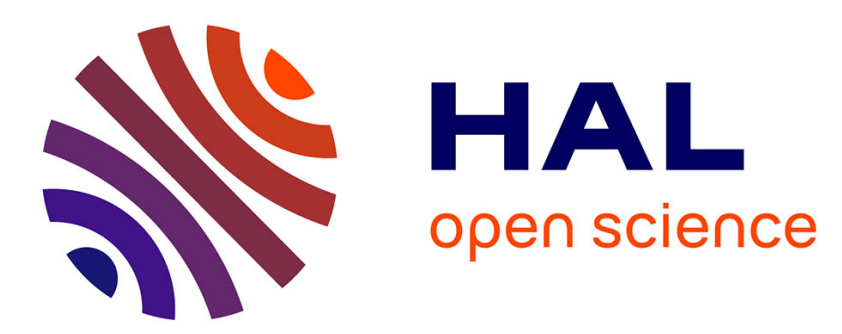

\title{
Battery Modeling Using Real Driving Cycle and Big-Bang Big-Crunch Algorithm
}

Loïc Vichard, Simon Morando, Alexandre Ravey, Fabien Harel, Pascal Venet, Serge Pelissier, Daniel Hissel

\section{- To cite this version:}

Loïc Vichard, Simon Morando, Alexandre Ravey, Fabien Harel, Pascal Venet, et al.. Battery Modeling Using Real Driving Cycle and Big-Bang Big-Crunch Algorithm. Transportation Electrification Conference and Expo, Jun 2018, Long Beach, CA, United States. 10.1109/ITEC.2018.8449951. hal-02300488

\section{HAL Id: hal-02300488 \\ https://hal.science/hal-02300488}

Submitted on 29 Sep 2019

HAL is a multi-disciplinary open access archive for the deposit and dissemination of scientific research documents, whether they are published or not. The documents may come from teaching and research institutions in France or abroad, or from public or private research centers.
L'archive ouverte pluridisciplinaire HAL, est destinée au dépôt et à la diffusion de documents scientifiques de niveau recherche, publiés ou non, émanant des établissements d'enseignement et de recherche français ou étrangers, des laboratoires publics ou privés. 


\title{
Battery modeling using real driving cycle and Big-Bang Big-Crunch algorithm
}

\author{
Loic Vichard $^{1,2}$, Simon Morando ${ }^{7}$, Alexandre Ravey ${ }^{1,2}$, Fabien Harel $^{3,6}$, Pascal Venet $^{3,5}$, Serge Pelissier ${ }^{6}$ \\ , Daniel Hissel ${ }^{3,4}$ \\ ${ }^{1}$ FEMTO-ST Institute, Univ. Bourgogne Franche-Comté, UTBM, CNRS \\ ${ }^{2}$ FCLAB, Univ. Bourgogne Franche-Comté, UTBM, CNRS \\ ${ }^{3}$ FCLAB, Univ. Bourgogne Franche-Comté, CNRS \\ ${ }^{4}$ FEMTO-ST Institute, Univ. Bourgogne Franche-Comté, CNRS \\ ${ }^{5}$ Univ Lyon, Université Claude Bernard Lyon 1, Ecole Centrale de Lyon, INSA Lyon, CNRS, Ampère, F-69622, Villeurbanne, France \\ ${ }^{6}$ Univ Lyon, IFSTTAR, AME, LTE F-69675, LYON, France \\ ${ }^{7}$ Faurecia Clean Mobility (FCM) - System Advanced Technologies - Powertrain 25500 BAVANS - France \\ Corresponding author: loic.vichard@utbm.fr
}

\begin{abstract}
The purpose of this study is to model battery packs integrated in a ten fuel cell hybrid electric vehicle fleet developed among the European project Mobypost dedicated to postal delivery applications. This project led to create and feed a big database as the vehicles were deeply monitored. Thanks to this database and Big-Bang Big-Crunch optimization algorithm this paper proposes a method to model battery using real driving cycle data in few minutes with a NRMSE less than 0.02 .
\end{abstract}

\section{INTRODUCTION}

With the growing popularity of Electric Vehicles (EVs) and fuel cell hybrid electric vehicles (FCHEVs), batteries used in those applications are now a famous topic [1]. However it is frequently pointed out that the batteries are still too expensive and a very critical part among the entire electric power-train. Indeed their lifetime and their autonomy are still a limitation to a worldwide deployment as it cannot compete internal combustion engine (ICE) yet. Consequently in order to improve the energy management of the batteries and thus their autonomy and lifetime, a good understanding of the dynamic behavior is required. This is why mathematical models are needed in order to represents and predict this dynamic behavior. Generally battery models are determined from battery characterizations by using constant current or simplified current profile. Models can also be determined by using impedance spectroscopy. These processes require to set up experiments needing equipment, cost and time. The purpose of this paper is to present a fast way to model a battery cell through a Thevenin Electrical Equivalent Circuit (EEC) by using an optimization algorithm and field use experimental data. The particularity of this study is the use of a rich database created from an ten fuel cell hybrid electric vehicle fleet.

In a first part the Mobypost European project and the vehicles will be presented. In a second part the data used to model the batteries will be enumerated. In a third part Thevenin representation and mathematical equations will be presented. Then, in a fourth part, the optimization algorithm used to identified the model parameters will be explained. Finally in fifth part the results will be illustrated and discussed to go on conclusion and perspectives.

\section{Mobypost PRoject}

\section{A. Concept}

The european project Mobypost aimed at developing and instrumenting a fleet of ten hybrid hydrogen vehicles powered by fuel cell for postal delivery applications (Fig. 1) [2], [3].

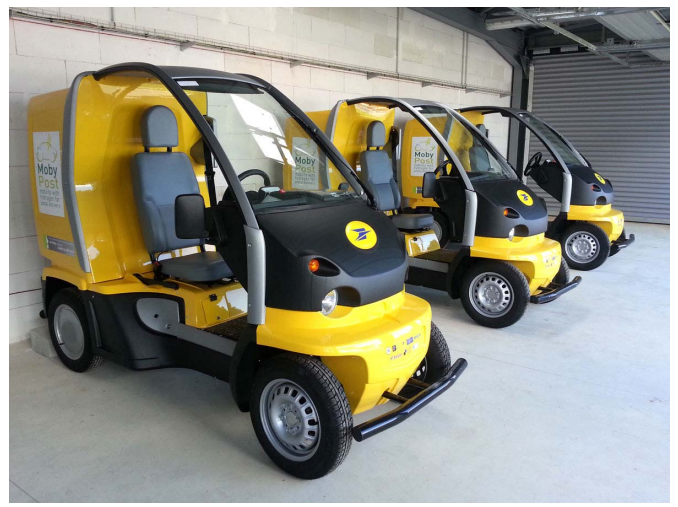

Fig. 1: 3 vehicles of the Mobypost fleet

The design of such vehicles, lightweigth hybrid electric including fuel cell and batteries, includes a powertrain design and components sizing taking into account the type of application : postal delivering services. The powertrain was designed using serie architecture by operating the fuel cell as a range extender [4], [5].

The battery pack is composed of four modules (U2412XP) connected in series and manufactured by Valence. Those modules, present a nominal voltage of $12.8 \mathrm{~V}$ and a nominal capacity of $110 \mathrm{Ah}$ measured with a current $\mathrm{C} / 5$ at $23^{\circ} \mathrm{C}$. Each module is also composed of four parallel $3.2 \mathrm{~V}$ $\mathrm{LiFeMgPO} 4$ cell groups in series.

\section{B. fleet monitoring and used data}

This project led to create a big database by monitoring ten postal delivery vehicles during almost three years. Physical 
values from sensors are measured and saved on a server every second [3]. Now an access to data of more than 1500 real driving cycles can be used to model the battery cells and observe the aging. In this study the data used are the battery current (Ibatt), the state of charge $(S O C)$, the battery cell voltage $(\mathrm{Vcell})$ and the battery temperature $(T)$.

The following figures Fig. 2 Fig. 3 Fig. 4 Fig. 5 illustrate the data mentioned above recorded during one postal delivery. This driving cycle was realized using the vehicle only in pure electric mod (fuel cell shutdown).

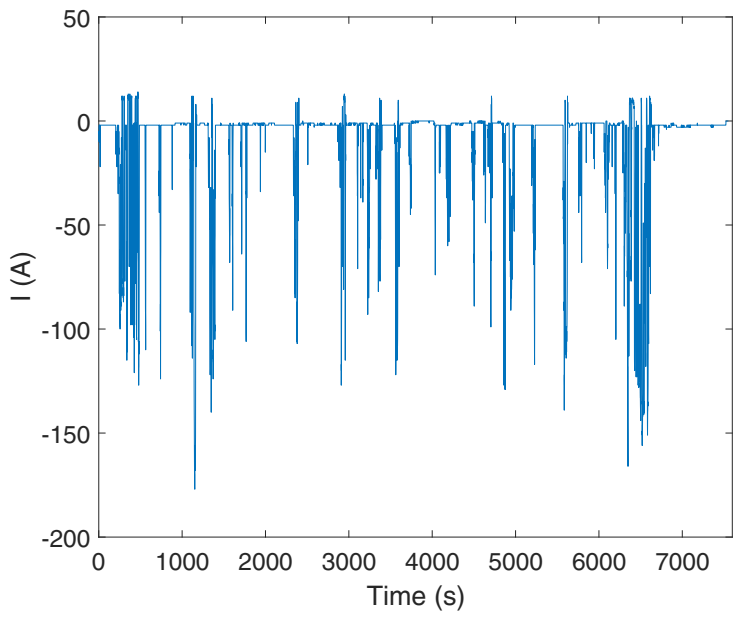

Fig. 2: Battery current during the driving cycle

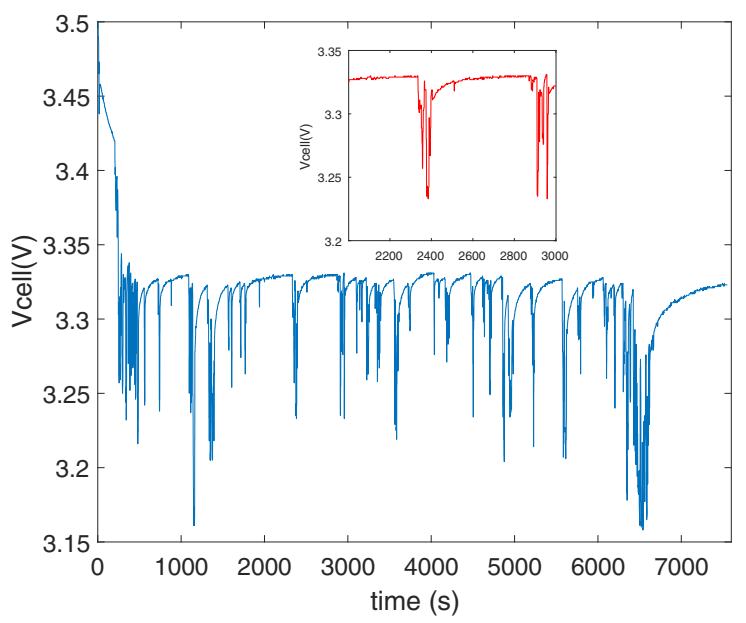

Fig. 3: Battery cell voltage in function of time

Fig. 4 illustrates the SOC evolution through this driving cycle. The SOC is determined by the battery management system developed by the battery manufacturer.

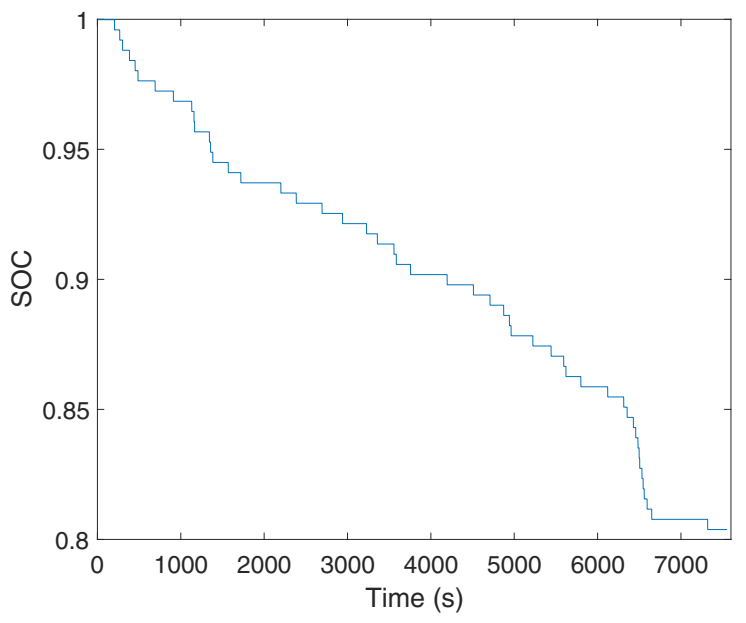

Fig. 4: State of charge evolution along the driving cycle

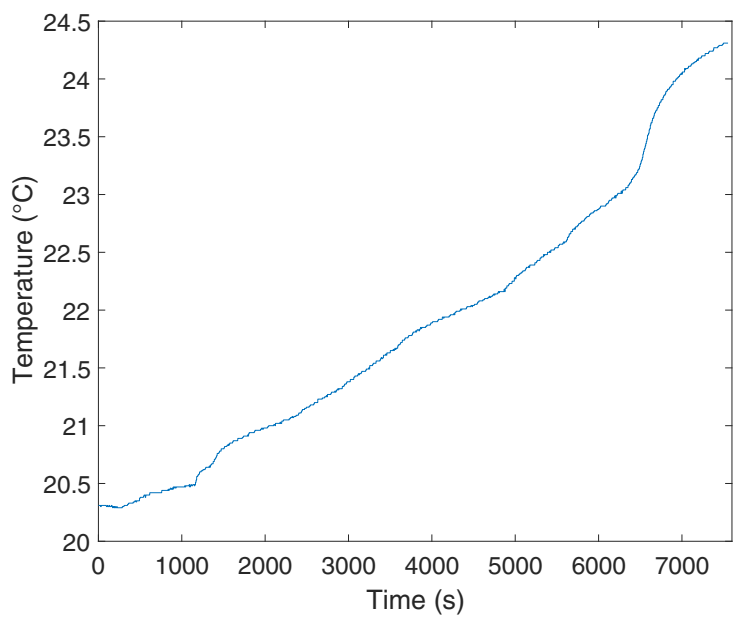

Fig. 5: Temperature evolution along the driving cycle

\section{BATTERY MODELING}

\section{A. Thevenin model}

Thevenin electrical equivalent circuit can be used to represent the temporal voltage response of a battery. Among all the equivalent circuits which can be found in the litterature, a most common structure is illustrated in the Fig. 6. The battery cell voltage response being composed of transient periods of many different duration, this is necessary to add several $\mathrm{R} / / \mathrm{C}$ circuits. The $\mathrm{R} / / \mathrm{C}$ circuits will get different time constants $(\tau)$ in order to make the model capable to reproduce larger interval of transient periods duration. In this structure, $\mathrm{R} / / \mathrm{C}$ series circuits are used to represent impedances linked to the charge transfers effects, double layer and diffusion effects. In the literature, models can be found integrating only one $\mathrm{R} / / \mathrm{C}$ circuit as in [6]-[8], with two R//C circuits [9]-[14], or again with three R//C circuits [15] [16]. 


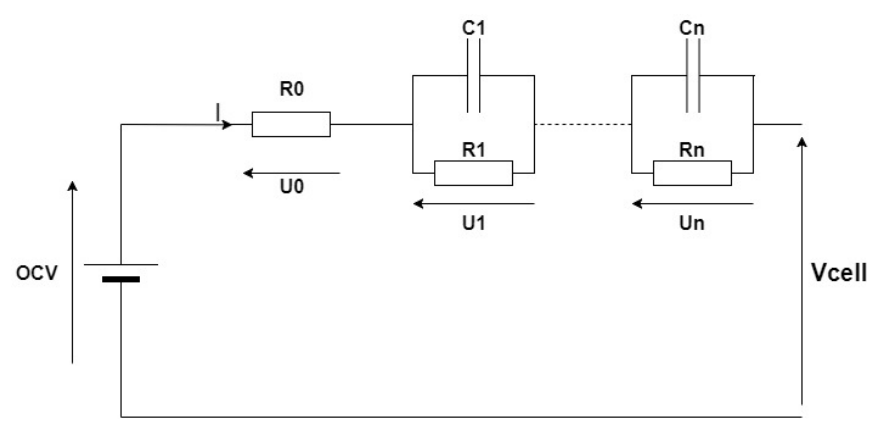

Fig. 6: Battery RC model

In this study the Thevenin structure is used with three $\mathrm{R} / / \mathrm{C}$ circuits in order to get more accuracy. Indeed these three $\mathrm{R} / / \mathrm{C}$ circuits are used to represent the charge/discharge phases, the diffusion phases and the relaxation phases.

\section{B. Model equations}

Using Kirchhoff's circuit laws from the Fig. 6 , the equation (1) can be used to determine Vcell, the estimated voltage response of the battery.

$$
\text { estimated }_{V \text { cell }}=O C V-U 0-U 1-\ldots-U n
$$

The next step is to resolve the differential equation (2) due to the capacitor. After having resolved (2), the equation (3) was deduced as solution in order to express Un. It has to be notified, since the acquisition frequency is $1 H z, t$ is then discretized with a range of 1 second to solve the equation.

$$
\dot{U n}=\frac{1}{C n} \cdot I-\frac{1}{R n \cdot C n} \cdot U n
$$

$U n(t)=U n(t-1) \cdot e^{-1 /(R n . C n)}+R n \cdot\left(1-e^{-1 /(R n . C n)}\right) \cdot I(t)$

In order to improve both accuracy and reality meaning, some dependencies have to be taken into account. Open Circuit Voltage (OCV) will be dependent on the SOC and on the Temperature as in the function (4). This OCV expression has been deduced during this study after a long work to find out how to reproduce OCV evolution versus the SOC and the temperature. Internal resistances will be dependent only on the temperature as in the function (5).

$$
\begin{aligned}
O C V(t) & =a+\frac{b \cdot(25-T(t))}{S O C(t)}+\frac{c}{S O C(t)}+d . S O C(t) \\
& +e \cdot \ln (S O C(t))+f . \ln (1.001-S O C(t)) \\
& +g \cdot \ln (1.01-S O C(t))+h . \exp (i . T(t))
\end{aligned}
$$

$a, b, c, d, e, f, g, h$ and $i$ being constants to be identified

$$
R_{n}(t)=a_{n} \cdot \exp \left(b_{n} \cdot T\right)
$$

$a_{n}$ and $b_{n}$ being constants to be identified

From these equations, an objective function can be deduced. Then an optimization algorithm is run using the objective function : Normalized Root Mean Square Error (NRMSE) (8) in order to determine the parameter values of the model. This NRMSE is obtained from the following equations : Error (6) and Root Mean Square Error (RMSE) (7).

$$
\text { Error }=\text { real }_{V \text { cell }}-\text { estimated }_{V \text { cell }}
$$

$$
\begin{gathered}
R M S E=\sqrt{\frac{1}{n} \cdot \sum_{i=1}^{n} \text { Error }^{2}} \\
N R M S E=\frac{R M S E}{\max _{\left(\text {real }_{V \text { cell }}\right)-\text { min }\left(\text { real }_{V \text { cell }}\right)}}
\end{gathered}
$$

\section{OPTIMIZATION ALGORITHM}

\section{A. Optimization concept}

Optimization problem can be summarized as finding the set of input parameters $\left(\mathrm{x}_{n}\right)$ minimizing a mathematical function $\mathrm{f}\left(\mathrm{x}_{n}\right)$. Nature is a main source for proposing optimization methods such as ant colony system (ACO), genetic algorithms (GA) or again big-bang big-crunch (BB-BC). In this paper, the objective is to identified the set of inputs parameters (parameters of the Thevenin structure), minimizing the NRMSE which means the estimated ${ }_{V \text { cell }}$ is as close as possible than the real $_{V \text { cell }}$.

\section{B. Big-Bang Big-Crunch algorithm}

In this study the BB-BC algorithm has been used. This optimization algorithm relies on one of the theories of the universe evolution [17] [18]. This theory, based on the general relativity of Einstein, explains that the expansion phase of the universe due to the big bang will end to be replaced by the big crunch phase which consists of the universe contraction.

This algorithm is used in this study as it shows good results and efficiency in [17]. It refers to the creation of the initial population randomly. This phase consists in spreading the candidates solutions all over the search space in an uniform manner.

The BB-BC optimization algorithm is based on the sequence of the following steps :

Step 1: Create an initial population of $\mathrm{N}_{p o p}$ candidates randomly, respecting the limits of the search space.

Step 2: Evaluate the objective function value of all candidate solutions from the initial population.

Step 3: Find the center of mass referring to the best candidate solution. (candidate giving the lower error).

Step 4: Calculate new candidates around the center of mass by adding or subtracting a normal random number which its value decreases as the iterations elapse (reduction of the search space). Also an exploration probability is integrated in order to get out of an eventual local minimum. 
Step 5: Return to step 2 until stopping criteria is met.

The reduction of the search space is represented by a function inversely proportional to the number of generation. The equation (9) illustrates the research space division according to the number of generations.

$$
R S_{d i v}(g e n)=\frac{1}{g e n}
$$

This function drastically reduces the search space for the first generations and this can lead to progress to a local minimum instead of the desired global minimum. In order to avoid this, another way to reduce the search space, proposed in [17], has been used in this study. Indeed this way divides more slowly the search space during first generations and then accelerate to find the results more efficiently. The proposed algorithm replaces the linear function by a translated exponential function.

It has to be specified that this algorithm is stochastic and to be sure to achieve the global minimum, an infinite number of iterations is required. In this study what is desired is a set of inputs parameters which will be able to reproduce the voltage for the entire temperature range with a good accuracy. Also as a short computing duration, is desired, a big population is avoided, and not a lot of generations are proceeded so here finding the global minimum is not the target.

\section{RESUlts}

Figures 7 and 10 compare the estimated battery voltage from the model regarding the real measured cell voltage from the database. The error that presents the model is $N R M S E=$ 0.0185 proving the effectiveness of the proposed method.

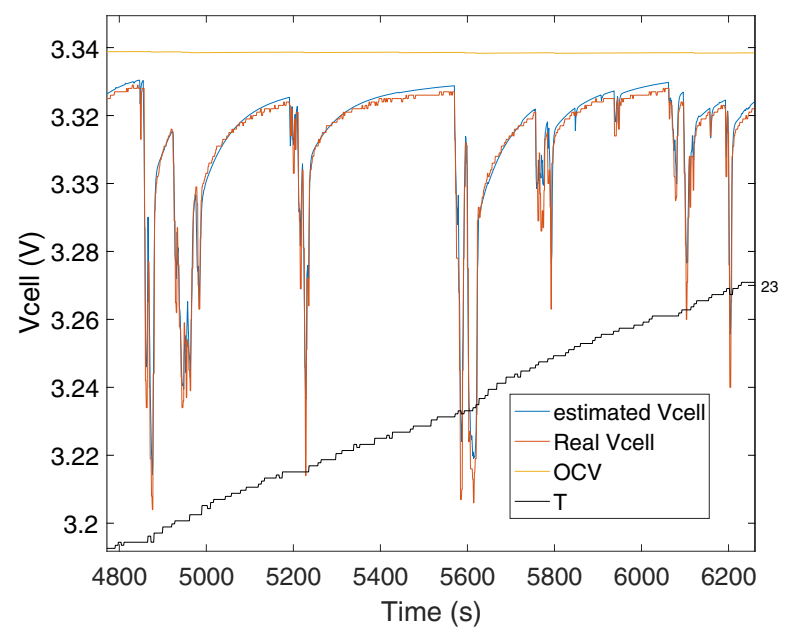

Fig. 7: Cell voltages comparison with driving cycle used for parameters identification

Tables I and II display the three average time constant values and their capacitance values for the driving cycle which was used for parameters identification. These tables also show the values of the constants in equations (4) and (5). The time constants present three different values, 2 seconds to reproduce charge transfer and double layer effects, 66 seconds and 500 secondes to reproduce both diffusion phenomena and relaxation phases. Regarding relaxation phenomena, to be able to better reproduce it at best, others $\mathrm{R} / / \mathrm{C}$ circuits should be added with higher time constants up to several hours [19]. The Fig. 8 illustrates the evolution of the internal resistance Rin (which is the sum of the four resistances) versus the temperature.

TABLE I: Model parameters values and time constants for $20.5^{\circ} \mathrm{C}<\mathrm{T}<24.5^{\circ} \mathrm{C}$

\begin{tabular}{|c|c|}
\hline Components & Values \\
\hline$\tau 1$ & $66 \mathrm{~s}$ \\
\hline$\tau 2$ & $2 \mathrm{~s}$ \\
\hline$\tau 3$ & $500 \mathrm{~s}$ \\
\hline$C 1$ & $72000 \mathrm{~F}$ \\
\hline$C 2$ & $2700 \mathrm{~F}$ \\
\hline$C 3$ & $500000 \mathrm{~F}$ \\
\hline$a$ & $3.22 \mathrm{~V}$ \\
\hline$b$ & $-0.001 \mathrm{~V} /{ }^{\circ} \mathrm{C}$ \\
\hline$c$ & $-0.0216 \mathrm{~V}$ \\
\hline$d$ & $0.182 \mathrm{~V}$ \\
\hline$e$ & $-0.0886 \mathrm{~V}$ \\
\hline$f$ & $-0.0632 \mathrm{~V}$ \\
\hline$g$ & $0.0778 \mathrm{~V}$ \\
\hline$h$ & $-0.001 \mathrm{~V}$ \\
\hline$i$ & $-0.5^{\circ} \mathrm{C}^{-1}$ \\
\hline
\end{tabular}

TABLE II: Model resistance coefficient values

\begin{tabular}{|c|c|c|}
\hline Resistance & $a_{n}$ & $b_{n}$ \\
\hline \hline$R 0$ & $0.0003 \Omega$ & $-0.0753^{\circ} C^{-1}$ \\
\hline$R 1$ & $0.0010 \Omega$ & $-0.0052{ }^{\circ} C^{-1}$ \\
\hline$R 2$ & $0.0013 \Omega$ & $-0.0301{ }^{\circ} C^{-1}$ \\
\hline$R 3$ & $0.0010 \Omega$ & $-0.0025{ }^{\circ} C^{-1}$ \\
\hline
\end{tabular}

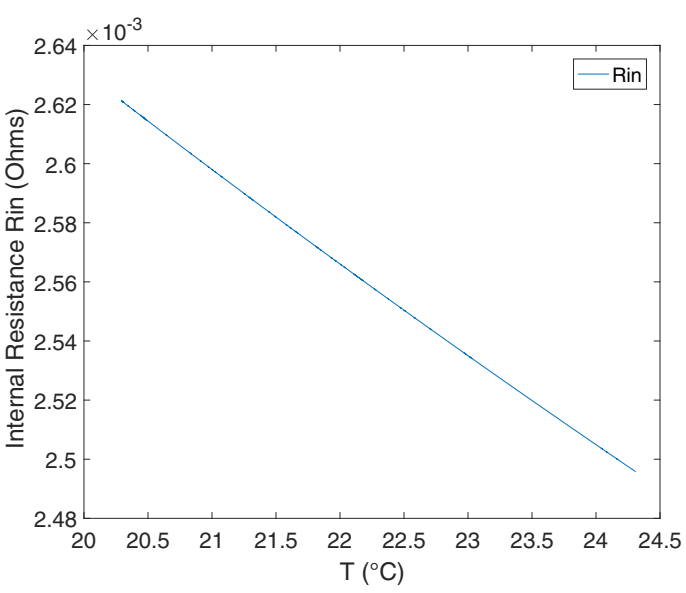

Fig. 8: Internal resistance evolution versus temperature

These results can lead to the following conclusion. The model is able to reproduce the voltage response of one driving 
cycle by taking into account the dependencies on the temperature and on the state of charge with a good accuracy after having identified the parameters. Here results are illustrated with the driving cycle which has been used to identify the parameters, so the method is not validated and it must be verified that the parameters are able to reproduce all the driving cycles of this battery.

\section{VALIDATION}

To validate this modeling and verify if the identified parameters are coherent, another driving cycle has to be reproduced to observe if the error remains low. To do that, a driving cycle where the temperature is between $5^{\circ} \mathrm{C}$ and $9^{\circ} \mathrm{C}$ was chosen. Figures 9 and 11 can validate the identified parameters as the model is able to adjust the voltage in function of the temperature range.

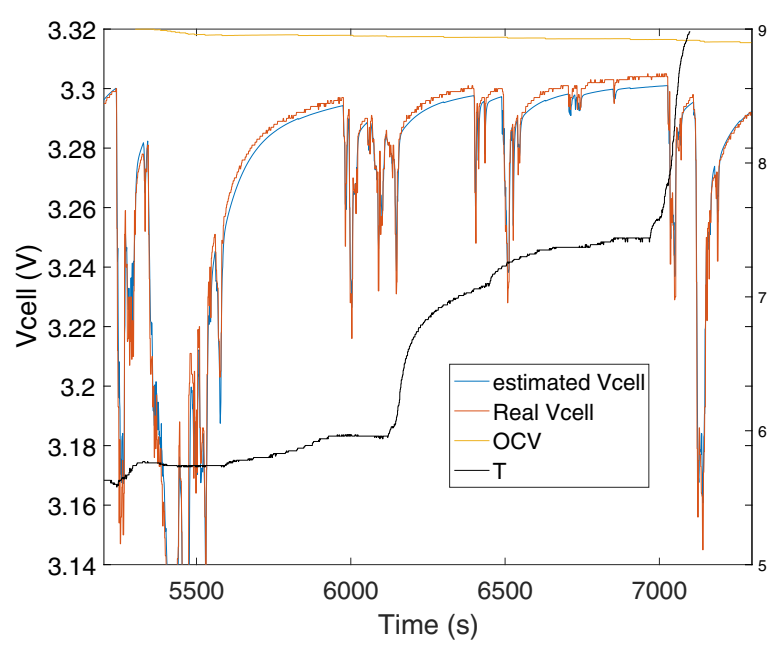

Fig. 9: Cell voltages comparison with driving cycle used for validation

\section{CONCLUSION AND PERSPECTIVES}

In this study a battery model for one driving cycle taking into account dependency on temperature and state of charge has been deduced by using a Thevenin electrical equivalent circuit and data directly extracted from real driving cycle through an optimization algorithm. This method presents a good accuracy and efficiency as the computing time is few minutes and the NRMSE is low. Future works should aim at optimizing again the dependency on the temperature and on the SOC.

\section{ACKNOWLEDGMENT}

This research work was funded by the region of FrancheComté, France.

\section{REFERENCES}

[1] B. Blunier, D. Bouquain, and A. Miraoui, "Fuel cells, energy management using fuel cells and supercapacitors," Alternative Propulsion Systems for Automobiles(Expert Verlag, 2008), pp. 97-116, 2008.
[2] A. Ravey, S. Faivre, C. Higel, F. Harel, and A. Djerdir, "Energy management of fuel cell electric vehicle with hydrid tanks," in IECON 2014 - 40th Annual Conference of the IEEE Industrial Electronics Society, Oct. 2014, pp. 3962-3967.

[3] L. Vichard, A. Ravey, S. Morando, F. Harel, P. Venet, S. Pelissier, and D. Hissel, "Battery aging study using field use data," in IEEE Vehicle Power and Propulsion Conference (VPPC), Dec. 2017.

[4] C. Higel, F. Harel, D. Candusso, S. Faivre, A. Ravey, D. Guilbert, A. Ndiaye, D. Bouquain, A. Djerdir, and A. Gaillard, "Part 1: Mobypost vehicles powertrain modeling, simulation and sizing," in Conference on Fundamentals and Development of Fuel Cells (FDFC 2013), 2013.

[5] S. Faivre, A. Ravey, D. Guilbert, A. Ndiaye, A. Gaillard, D. Bouquain, A. Djerdir, C. Higel, F. Harel, and D. Candusso, "Part 2-mobypost vehicles powertrain design and experimental validation," in International Conference on Fundamentals and Development of Fuel Cells (FDFC 2013), 2013.

[6] S. Tian, M. Hong, and M. Ouyang, "An experimental study and nonlinear modeling of discharge $\mathrm{i}-\mathrm{v}$ behavior of valve-regulated leadacid batteries," IEEE transactions on Energy Conversion, vol. 24, no. 2, pp. 452-458, 2009.

[7] B. Y. Liaw, G. Nagasubramanian, R. G. Jungst, and D. H. Doughty, "Modeling of lithium ion cellsa simple equivalent-circuit model approach," Solid state ionics, vol. 175, no. 1, pp. 835-839, 2004.

[8] M. Dubarry and B. Y. Liaw, "Development of a universal modeling tool for rechargeable lithium batteries," Journal of Power Sources, vol. 174, no. 2, pp. 856-860, 2007.

[9] M. Chen and G. A. Rincon-Mora, "Accurate electrical battery model capable of predicting runtime and iv performance," IEEE transactions on energy conversion, vol. 21, no. 2, pp. 504-511, 2006.

[10] J. Zhang, S. Ci, H. Sharif, and M. Alahmad, "An enhanced circuit-based model for single-cell battery," in Applied Power Electronics Conference and Exposition (APEC), 2010 Twenty-Fifth Annual IEEE. IEEE, 2010, pp. 672-675.

[11] B. Schweighofer, K. M. Raab, and G. Brasseur, "Modeling of high power automotive batteries by the use of an automated test system," IEEE transactions on instrumentation and measurement, vol. 52, no. 4, pp. 1087-1091, 2003.

[12] S. Abu-Sharkh and D. Doerffel, "Rapid test and non-linear model characterisation of solid-state lithium-ion batteries," Journal of Power Sources, vol. 130, no. 1, pp. 266-274, 2004.

[13] S. Barsali and M. Ceraolo, "Dynamical models of lead-acid batteries: Implementation issues," IEEE Transactions on energy conversion, vol. 17, no. 1, pp. 16-23, 2002.

[14] Y. Hu, S. Yurkovich, Y. Guezennec, and B. Yurkovich, "A technique for dynamic battery model identification in automotive applications using linear parameter varying structures," Control Engineering Practice, vol. 17, no. 10, pp. 1190-1201, 2009.

[15] R. C. Kroeze and P. T. Krein, "Electrical battery model for use in dynamic electric vehicle simulations," in Power Electronics Specialists Conference, 2008. PESC 2008. IEEE. IEEE, 2008, pp. 1336-1342.

[16] Y. Hu, S. Yurkovich, Y. Guezennec, and B. Yurkovich, "Electro-thermal battery model identification for automotive applications," Journal of Power Sources, vol. 196, no. 1, pp. 449-457, 2011.

[17] S. Morando, M. Pera, N. Youfi Steiner, S. Jemei, D. Hissel, and L. Larger, "Reservoir computing optimisation for pem fuel cell fault diagnostic," in IEEE Vehicle Power and Propulsion Conference (VPPC), Dec. 2017.

[18] O. K. Erol and I. Eksin, "A new optimization method: big bang-big crunch," Advances in Engineering Software, vol. 37, no. 2, pp. 106111, 2006.

[19] A. Li, S. Pelissier, P. Venet, and P. Gyan, "Fast characterization method for modeling battery relaxation voltage," Batteries, vol. 2, no. 2, pp. $1-15,2016$. 


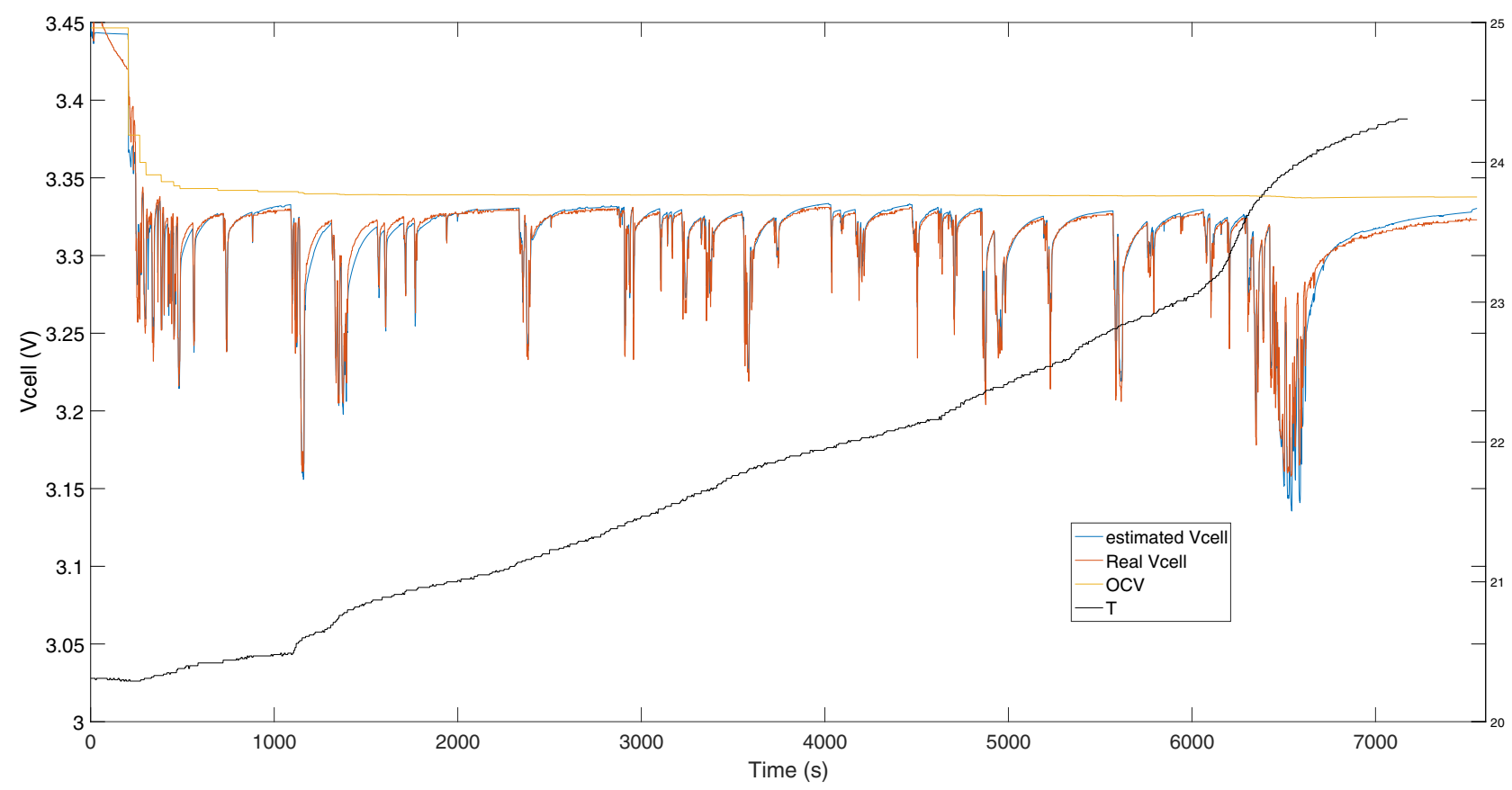

Fig. 10: Cell voltages comparison with entire driving cycle used for parameters identification

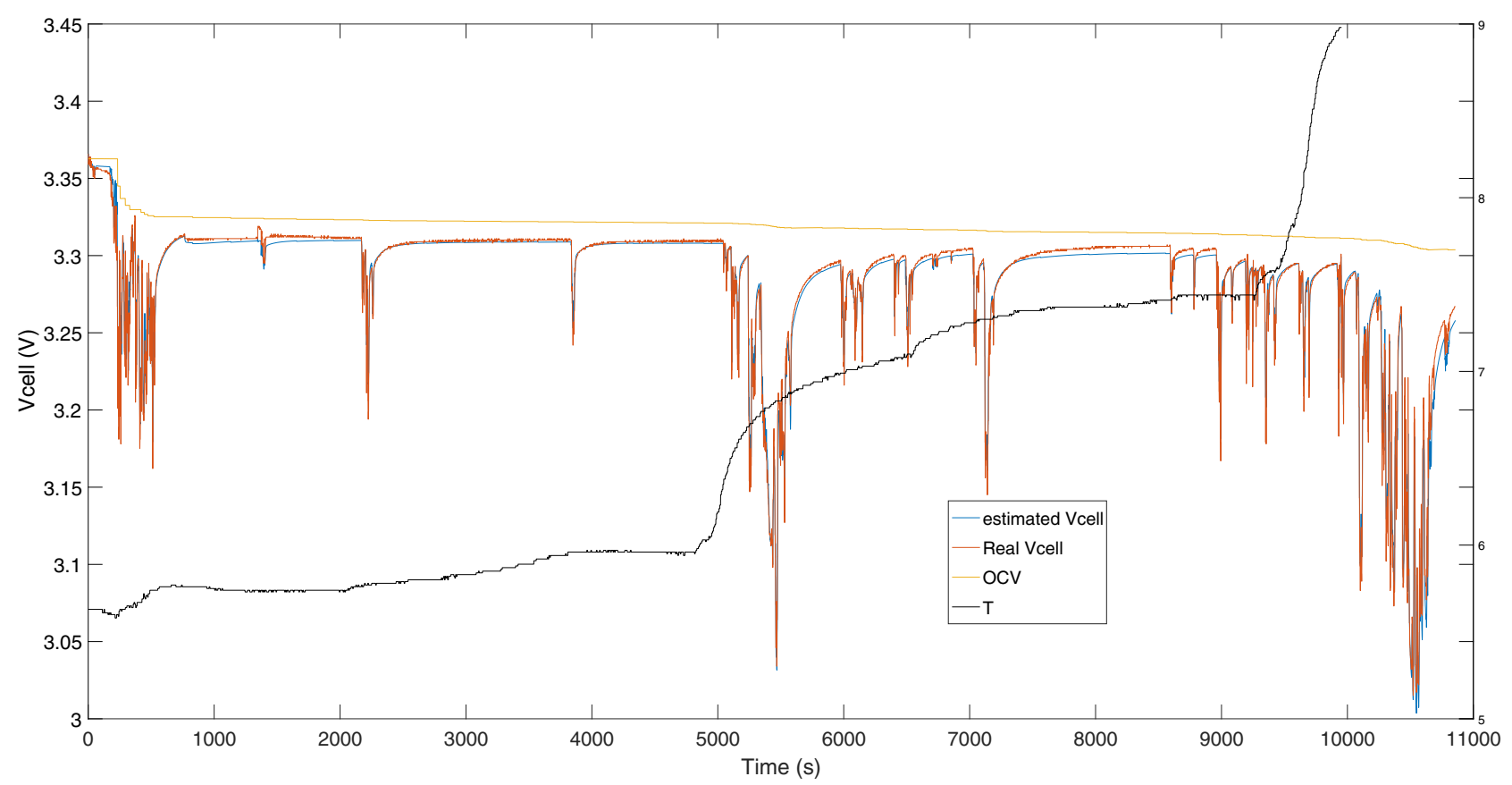

Fig. 11: Cell voltages comparison with entire driving cycle used for validation 